CATALLAXY

Volume 5 Issue 2 December 2020

e-ISSN 2544-090X

¿ www.catallaxy.pl

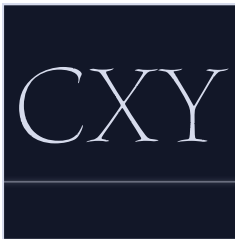

Original article

received: 10.11 .2020 / accepted: 15.12 .2020 / published online: 31.12 .2020

Owczarczuk, M. (2020). Institutional competitiveness of Central and Eastern European countries and the inflow of foreign direct investments. Catallaxy, 5(2): 87-96. doi:10.24136/cxy.2020.008.

\title{
Institutional competitiveness of Central and Eastern European countries and the inflow of foreign direct investments
}

\author{
MAGDALENA OWCZARCZUK \\ University of Biatystok, Faculty of Economics and Finance, Department of Political Economy, ul. Warszawska 63A, 15- \\ 062 Biatystok, Poland \\ \m.owczarczuk@uwb.edu.pl \\ (D) orcid.org/0000-0002-9337-1657
}

\begin{abstract}
Motivation: Central and Eastern European countries (CEE) in spite of a long period of European Union membership and integration with the developed economies of Western Europe are still on the path of convergence, i.e. pursuing the highly developed countries in terms of, among others, GDP per capita. Assuming that the FDI inflow carries numerous benefits for the economic growth of the recipient country, those economies still compete against one another for foreign capital. One of the factors that attracts FDI is high quality of institutional surrounding.

Aim: assessment of institutional competitiveness of the selected CEE countries (Czech Republic, Estonia, Lithuania, Latvia, Poland, Slovakia, Slovenia, Hungary) as well as verification of the relationship between institutional competitiveness and the FDI inflow to the analyzed economies.

Materials and methods: The article reviews positions obtained by the selected CEE countries in the ranking of competitiveness published by Global Economic Forum (Global Competitiveness Report). The analysis and assessment of CEE countries competitiveness focused around the institutional quality assessment. Quantitatively, the connection was revealed between competitiveness ranking in the field of institutions and FDI inflow per capita and FDI as \% of GDP to the economies under consideration.

Results: the analysis of the global competitiveness index ( $\mathrm{GCI}$ ) allows to notice that among the CEE countries, Estonia is characterized with the highest institutional competitiveness. The detailed analysis indicated that low social capital quality decreases institutional competitiveness in case of all analyzed economies. The conducted quantitative analysis of the potential link between the GCI-Pillar 1. Institutions index and the inflow of foreign direct investments to CEE countries indicates the positive correlation of those variables. Higher index values (institution quality assessment) corresponds to the higher FDI per capita level and FDI calculated as GDP percentage.
\end{abstract}

Keywords: FDI; competitiveness; institutions; GCI; institutional surrounding; CEE countries JEL: E02; F21; G11; O17; P48

\section{Introduction}

Foreign direct investments (FDI) are still a desired factor for growth and development of $\mathrm{CEE}$ region economies due to the fact that they constitute a collection of either material as well as non-material sources that can stimulate further growth and development of those economies. Due to that, attracting greater number of FDI is one of the key ob- 
jectives of those countries' economies, which means that either among scientists as well as politicians the question which factors lead to greater inflow of FDI is still valid.

Literature review reveals that an increasingly important role in theories and research, explaining foreign investments functioning, is played by factors of institutional character (Dunning, 2006, pp. 173-228; Kapas, 2020, pp. 161-189). It can be noticed that new institutional economy accepted the role of institutions in economic development (e.g. Acemoglu \& Robinson, 2012; North, 1990) prompting more authors to undertake efforts leading to the analysis of the impact of institutional investments on international capital flows. Therefore, there is a need for further research and analysis pertaining to institutional determiners of FDI inflows to various economies, including the post-socialist ones.

The economies' institutional surrounding quality is most often examined from the point of view of international economies' competitiveness and bridging the gap existing in this scope between national economic institutions and world leaders. A good example of competitiveness measure is Global Competitiveness Index - published by World Economic Forum. In the construction of the index, institutions' quality constitutes the so called first pillar, belonging to the group of 'basic requirements' indices.

The primary objective of the article is the assessment of institutional competitiveness of the selected CEE countries (Czech Republic, Estonia, Lithuania, Latvia, Poland, Slovakia, Slovenia, Hungary) as well as verification of the potential relationship between the economy's institutional surrounding quality measured by Competitiveness index and the inflow of foreign direct investments to the analyzed CEE countries. Therefore, the analysis of shaping the GCI-1 Pillar Institutions index in CEE countries for the years 2007-2019 shall be conducted. Next, the analysis of the correlations between the acquired level of GCI-1 Pillar Institutions (institutions quality) and the inflow of FDI to the CEE countries in 2007-2019 shall be carried out.
2. Institutional competitiveness and FDI inflow: studies review

In the available literature, there are many approaches to and the meanings of 'institutions.' The institutions are the research subject of numerous scientific disciplines, including sociology (Powell \& di Maggio, 1991), law, political science (Immergut, 1998, pp. 5-34; Streeck \& Thelen, 2005), or economics (e.g. Czech, 2019; Hodgson, 2006, pp.1-25; North, 1990; Wilkin, 2016; Williamson, 2000, pp. 595-613). One of the most utilized definitions in the field of economic research is the one proposed by D.C. North (1990, p. 3). According to it, institutions are 'the rules of the game in the society.' Institutions are relatively durable elements of the society and economy. They constitute formal or informal rules (formulas) of individuals behavior, which limit or stimulate their activities by influencing economic activity, i.e. production, allocation, goods and services distribution process. Czech (2019) provides as many as eight approaches to the term institution by simultaneously stating that the division conducted by him does not exhaust the topic but allows to notice the wide analytical utility of the category. Among the meanings enumerated by him, it is worth indicating the understanding of institutions as: rules, restrictions, thoughts and behavior patterns, balance points, structures, means to achieve the objective, organization, or signs and symbols.

Therefore, institutions can be treated as specific resources, which by influencing the development of the company's strategic resources, impact the probability of success of various corporation strategies (Wan, 2005, pp. 161-182). Institutional conditioning of activities can provide companies with the possibility to utilize skills specific for the particular enterprise (Jackson \& Deeg, 2008, pp. 540-561). Also Dunning (2006, pp. 173-228), the author of the eclectic theory of international capital flows (called the OLI paradigm - Ownership, Location, Internalization), extended the concept of New Development Paradigm (NDP) to institutions and institutional infrastructure (including 
social capital). By modifying the OLI paradigm, he introduces the concept of institutionally conditioned competitive advantage (as the $\mathrm{O}$ part, i.e. the advantages resulting from the possessed resources and company's capabilities).

Increasingly more often institutions are viewed as a part of national business systems that create certain economic rules of the game that shape strategies, structures and companies' competitiveness (Morgan, 2007, pp. 127-145). The shape of a particular national business system depends on the development path of the country adopted and implemented by the government. Therefore, frequently in the literature, institutions' quality is being discussed on the ground of research on the concept of the so called good governance. Kauffman et al. (2011, pp. 220-246) defines governance way as the set of processes and institutions through which the power in the particular country is being exercised. Due to this, institutional activity of the country shall also be a part of its investment climate. Among many factors influencing the location decisions of enterprises, including foreign direct investments, institutional factors are also significant. The relationship between a foreign investor and the country conditions the character and possibilities of the conducted activity. The country creates the environment in which businessmen act and the quality of it depends on the success of the adopted measures. Due to this, institutional surrounding of enterprises should be treated as a significant condition of FDI inflow to the given country.

Numerous research and analysis indicate that property rights and regulations are two most important factors shaping the location decisions of trans-national corporations (Angeles, 2011, pp. 157-177; Asiedu \& Lien, 2011, pp. 99-111; Bailey, 2018, pp. 139-148; Choi et al., 2016, pp. 114-123; Contractor et al., 2020, pp. 1-13; Tanaka \& Iwaisako, 2014, pp. 107-124). Durable and stable regulation environment decreases uncertainty by safeguarding multinational enterprises and allowing foreign competition and by these eliminates market imperfections, which also fosters effi- ciency and improves profitability. Moreover, it is assumed that strong security and protection of property rights are the basis for economic decision making process in market economies (Gruszewska, 2020, pp. 43-63).

In location theory, the adoption of FDI was conditioned by competitive advantage of the particular area (Dunning, 1973; Rugman, 1980; Tesch, 1980), which can act positively on the development processes of enterprises. Therefore, particular countries compete against each other for FDI also with institutional surrounding quality.

Referring to the factor definition of competitiveness, it can be indicated that institutional competitiveness is the state's ability to generate growth in conditions of changes in global economy by creating possibilities for the activity of market players. Campbell \& Pedersen (2007, pp. 230-246) understands institutional competitiveness as a country's ability to achieve social and economic success due to its political, economic and cultural institutions. This approach focuses around the issue of assessing the economy competitiveness source, which in the future can reflect specific competitive position of the particular country.

Countries pursuit to possess the best possible collection of institutions is also called systemic competition (Huemer et al., 2013, p. 578), however, as Bochańczyk-Kupka (2011, pp. 8-23) states, institutional competitiveness focuses its attention on assessing those institutions that are the subject of analysis of economic system in a narrow sense. With competitiveness assessment of an economic system, it is important to compare economic freedom, entrepreneurship, institution quality, ownership, risk, investment attractiveness, corporate governance, entities' behavior as well as numerous non-economic factors that define international position of a country (Bossak, 2006, p. 130). Institutional competitiveness can be understood as attractiveness of the general institutional frames of a country for economic entities, which conduct economic activity there (Huemer et al., 2013, p. 581). 


\section{Materials and methods}

The primary objective of the conducted research is the assessment of institutional competitiveness of CEE countries as well as verification of the potential link between economy's institutional competitiveness and the inflow of foreign direct investments.

The comparative and descriptive analysis as well as critical analysis of the subject literature were used in the research. Empirical analysis was conducted for the selected CEE countries (Czech Republic, Estonia, Latvia, Lithuania, Poland, Slovakia, Slovenia, Hungary), which underwent specific development stages in similar periods (transformation, entering the European Union).

In the analysis and assessment of institutional competitiveness the data was used from the Global Competitiveness Index ranking conducted by Global Economic Forum. Data from 2019 served also for more detailed analysis of institutional competitiveness factors of particular economies. Competitiveness index in the institutions field is elaborated on the basis of 8 sub-indices described by 26 variables.

Verification of potential relationship between institutional competitiveness and FDI inflow was conducted on the basis of data from UNCTADstat (2020). For the analysis of correlations, the following measures were used: FDI inflow per capita as well as FDI inflow as GDP \%. Due to restricted availability of data pertaining to institutional competitiveness, the analysis covered the years 2007-2019.

\section{Results}

Institutions' quality, according to competitiveness index in CEE countries, is rather variable. In 2019, the highest position in the ranking in terms of institutions quality was achieved by Estonia that positioned itself at 21 place out of 141 global economies with the result of 70.9. Slovenia, Lithuania, Czech Republic, Latvia, Poland, Slovakia and Hungary were lower in the ranking (see Table 1 ). The very competitive position achieved by Estonia positions it among highly developed countries of the European Union. The other CEE countries hold the last positions in the institutional competitiveness ranking of the European Union countries. It is worth noticing that in each of the mentioned countries, institutional field gained worse assessment than the general competitiveness of the country. It only means that institutional environment of particular CEE economies still decreases their competitiveness.

The detailed analysis of individual components of index measuring institutional competitiveness (see Table 2) confirms that in almost every of its elements Estonia gained the best results. On the other hand, Poland, Slovakia and Hungary are the countries that most frequently achieved the lowest results in the sub-indices under consideration.

CEE economies vary among themselves in terms of institutions' quality. By analyzing particular elements of GCI index Pillar 1, it can be indicated which components increase and which ones decrease institutional competitiveness of particular countries. It can be noticed that the sub-index 'security' in every of the analyzed economies gained values above average. However, it can be observed that the greatest problem in building competitiveness of CEE countries becomes social capital, which was assessed rather low (below average) in each of the analyzed economies. The weakness of CEE countries in building trust as well as social capital probably lies in post-socialist past and the way the citizens were treated by the state (authorities) and the law.

On the basis of data from the Global Competitiveness Report, it can be noticed that almost all of the described CEE economies in the analyzed period improved institutions' quality. Only in Estonia, a slight decrease in the index value was observed in relation to 2007. However, competitiveness increase does not only stem from the improvement in institutional surrounding, but more from achieving better results than others. Data gathered in Chart 1 reveals that in spite of visible fluctuations of institutional competitiveness 
index, ultimately in 2019, many economies stayed at similar positions in the ranking to the year 2007 in relation to other countries of the region. Only Slovenia managed to move from 4 to 2 position in the region and as for now it maintains it for the longest period of time - i.e. 7 years. Visibly positive index changes that began in 2013, can also be observed in Czech Republic and Lithuania. The indices in Poland are distinctly different, as from 2010, the visible drop in competitive position in the field of institutions can be observed. Weak and worsening position of institutions' quality assessment in Poland can stem, among other things, from the complexities and inaccuracies of law, low efficiency of it, faulty judicial system, lack of future orientation of government or low level of social capital (Owczarczuk, 2014, pp. 168-170; Schwab, 2019, p. 467). Obeying and enforcing legal norms in a particular country translates into confidence in investment security in a given economy. It seems, therefore, that independent and efficient judicial system additionally increases investment and business attractiveness of a country (Owczarczuk, 2020, p. 168).

Differences in institutional surrounding quality underlie many discrepancies between countries in the field of e.g. technology, human capital as well as physical capital, including FDI. Numerous research and analysis confirm that location decisions of enterprises also depend on institutional factors. The basic FDI institutional conditions are composed of rules and regulations pertaining to the entry and functioning of foreign investors, standards of treating entities with foreign capital participation as well as rules for market functioning, including especially rules for competition as well as takeovers and mergers. Those conditions are so significant because they determine the very investment decision. However, they impact equivocally the location, i.e. changes directed at improving country's openness create the conditions, but do not guarantee FDI inflow and lack of such changes causes significant restrictions and even lack of FDI.

Therefore, legal regulations of the host country determine the scope of acceptable solutions and practices consistent with legal and economic system functioning in a particular country. Companies functioning in particular institutional conditions face numerous challenges in everyday activity and coping with them can be a crucial element of their existence on the market. Entrepreneurs will not undertake foreign direct investments if they are forced to devote too much time and money on securing their possession as well as monitoring if the contractual obligations are fulfilled correctly. From the country where they allocate capital, they expect proper level of trust in a society, providing basic level of security and executing property right by public institutions, proper transparency of rules, efficiency and control by public bodies, or proper standards of corporate governance and business ethics (Schwab, 2018, p. 12).

Positive relationship between competitiveness index and the inflow of foreign direct investments is proved by correlation analyses conducted on the example of CEE countries. GCI index (for Pillar 1. Institutions), in more than $60 \%$ can explain the variability of FDI per capita size and in more than $48 \%$ - the variability of FDI in GDP of CEE countries (Chart 2 and Chart 3 ). The relatively high $\mathrm{R}^{2}$ coefficient is obtained mostly due to Estonia, which gained either very good results in the aforementioned ranking as well as solid relative values of the inflowing capital in the form of FDI. After excluding Estonia from the group of analyzed countries, the quantitative relationship between FDI inflow and competitiveness index is not that obvious. Bearing in mind the imperfection of the method used, it should be stated that it is only the complementation of formerly conducted theoretical solutions.

\section{Conclusion}

The aim of the conducted research was the assessment of institutional competitiveness of the selected CEE countries on the basis of Global Competitiveness Index as well as verification of the potential link between the obtained index level and the FDI inflow in those countries. Conducted analyses 
proved that the most competitive economy among CEE countries in the field of institutions is Estonia. Beginning from 2007, this country has achieved high notes in competitiveness ranking exceeding sometimes even highly developed countries of Western Europe. Also Estonia during the last three years (2017-2019) noted unbeatably highest levels of FDI per capita inflow in ECC region. Slovenia, Czech Republic and Lithuania do relatively well in the assessment of institutional competitiveness as well as in attracting FDI per capita. Among the analyzed economies, it is worth indicating that in Poland from 2010, the deterioration in institutions' quality has been observed. It can be assumed that this process results in one of the lowest in CEE values of FDI per capita. Moreover, the detailed analysis of competitiveness index indicated that in case of each of the analyzed economies, institutional competitiveness decreases low value of social capital.

The conducted review of the existing research as well as quantitative analysis of the relationship between GCI-Pillar 1. Institutions and the inflow of FDI to CEE countries indicate the positive correlation of those variables. Higher value of the index (institutions quality assessment) translates into higher level of FDI per capita and FDI calculated as GDP percentage.

In spite of the imperfections of the utilized indicators and rankings, when assessing institutions, it should be remembered that they are also the source of information for the potential foreign investors. Due to this, in order to increase investment attractiveness, CEE countries should make efforts connected with improving and facilitating institutional environment.

\section{References}

Acemoglu, D., \& Robinson, J.A. (2012). Why nations fail: the origins of power, prosperity and poverty. New York: Crown Publishers.
Angeles, L. (2011). Institutions, property rights, and economic development in historical perspective. Kyklos, 64(2). doi:10.1111/j.1467-6435.2011.00500.x.

Asiedu, E., \& Lien, D. (2011). Democracy, foreign direct investment and natural resources. Journal of International Economics, 84(1). doi:10.1016/j. jinteco.2010.12.001.

Bailey, N. (2018). Exploring the relationship between institutional factors and FDI attractiveness: a meta-analytic review. International Business Review, 27(1). doi:10.1016/j. ibusrev.2017.05.012.

Bochańczyk-Kupka, D. (2011). Systemic and institutional competitiveness of economic system. Journal of Economics $\mathcal{E}$ Management, 7(1).

Bossak, J.W. (2006). Systemy gospodarcze a globalna konkurencja. Warszawa: SGH.

Campbell, J.L., \& Pedersen, O.K. (2007). Institutional Competitiveness in the global economy: Denmark, the United States, and the varieties of capitalism. Regulation E Governance, 1(3). doi:10.1111/j.1748-5991.2007.00012.x.

Choi, J.J., Lee, S.M., Shoham, A. (2016). The effects of institutional distance on FDI inflow: general environmental institutions (GEI) versus minority investor protection institutions (MIP). International Business Review, 25 (1). doi:10.1016/j.ibusrev.2014.11.010.

Contractor, F., Dangol, R., Nuruzzaman, N., \& Raghunath, S. (2020). How do country regulations and business environment impact foreign direct investment (FDI) inflows. International Business Review, 29(2). doi:10.1016/j. ibusrev.2019.101640.

Czech, S. (2019). Od konfliktu do kooperacji: instytucjonalizacja konfliktu interesów zbiorowych w szwedzkim modelu gospodarczym. Warszawa: Scholar.

Dunning, J.H. (1973). The determinants of international production. Oxford Economic Papers, 25(3). doi:10.1093/oxfordjournals.oep. a041261.

Dunning, J.H. (2006). Towards a new paradigm of development: implications for the determinants of international business activity. Transnational Corporations, 15(1).

Gruszewska, E. (2020). Ekonomiczne aspekty praw własności: perspektywa instytucjonalna. In E. Gruszewska, \& R. Przygodzka (Eds.), Instytucjonalne $i$ strukturalne aspekty rozwoju rolnictwa i obszarów wiejskich: księga poświęcona pamięci dr. hab. Adama Sadowskiego, prof. UwB. Białystok: Uniwersytet w Białymstoku. doi:10.15290/ isarrow.2020.01. 
Hodgson, G.M. (2006). What are institutions. Journal of Economic Issues, 40(1). doi:10.1080/00213 624.2006.11506879.

Huemer, S., Scheubel, B., \& Walch, F. (2013). Measuring institutional competitiveness in Europe. CESifo Economic Studies, 59(3). doi:10.1093/ cesifo/ift002.

Immergut, E.M. (1998). The theoretical core of the new institutionalism. Politics $\mathcal{E}$ Society, 26(1). doi:10.1177/0032329298026001002.

Jackson, G., \& Deeg, R. (2008). Comparing capitalisms: understanding institutional diversity and its implications for international business. Journal of International Business Studies, 39. doi:10.1057/palgrave.jibs.8400375.

Kapas, J. (2020). Formal and informal institutions, and FDI flows: a review of the empirical literature and proposition for further research. Economic and Business Review, 22(1). doi:10.15458/ ebr100.

Kaufmann, D., Kraay, A., \& Mastruzzi, M. (2011). The worldwide governance indicators: methodology and analytical issues. Hague Journal on the Rule Law, 3(2). doi:10.1017/ S1876404511200046.

Morgan, G. (2007). National business systems research: progress and prospects. Scandinavian Journal of Management, 23(2). doi:10.1016/j. scaman.2007.02.008.

North, D.C. (1990). Institutions, institutional change and economic performance. Cambridge: Cambridge University Press. doi:10.1017/ CBO9780511808678.

Owczarczuk, M. (2014). Atrakcyjność inwestycyjna Polski z perspektywy instytucjonalnej. Zeszyty Naukowe Uniwersytetu Ekonomicznego w Katowicach. Studia Ekonomiczne, 184.

Owczarczuk, M. (2020). Instytucje a napływ bezpośrednich inwestycji zagranicznych do Polski. Białystok: Uniwersytet w Białymstoku.

Powell, W.W., \& di Maggio, P.J. (Eds.). (1991). The new institutionalism in organizational analysis. Chicago: University of Chicago Press.
Rugman, M. (1980). Internationalization as a general theory of foreign direct investment: a re-appraisal of the literature. Review of World Economics, 116. doi:10.1007/BF02696864.

Schwab, K. (Ed.). (2018). The global competitiveness report 2018. Retrieved 01.12.2020 from http:// www3.weforum.org.

Schwab, K. (Ed.). (2019) The global competitiveness report 2019. Retrieved 01.12.2020 from http:// www3.weforum.org.

Streeck, W., \& Thelen, K. (Eds.). (2005). Beyond continuity: exploration in the dynamics of advanced political economies. Oxford: Oxford University Press.

Tanaka, H., \& Iwaisako, T. (2014). Intellectual property rights and foreign direct investment: a welfare analysis. European Economic Review, 67. doi:10.1016/j.euroecorev.2014.01.013.

Tesch, P. (1980). Die Bestimmungsgründe des Internationalen Handels und der Direktinvestitionen. Berlin: Dunker und Humblot.

UNCTADstat. (2020). Retrieved 28.12.2020 from https://unctadstat.unctad.org.

Wan, W.P. (2005). Country resource environments, firm capabilities, and corporate diversification strategies. Journal of Management Studies, 42(1). doi:10.1111/j.1467-6486.2005.00492.x.

Wilkin, J. (2016). Instytucjonalne i kulturowe podstawy gospodarowania. Warszawa: Scholar.

Williamson, O.E. (2000). The New Institutional Economics: Taking Stocks, Looking Ahead. Journal of Economics Literature, 38(3).

World Bank. (2020). Global Competitiveness Index. Retrieved 01.12.2020 from https://govdata360. worldbank.org.

Acknowledgements

Author contributions: author have given approval to the final version of the article.

Funding: this research was fully funded by the author's own sources. 
Appendix

Table 1.

Global Competitiveness Index 2019 (GCI 4.0) in CEE countries

\begin{tabular}{lcc}
\hline \multicolumn{1}{c}{ Economy } & Overall score & Pillar 1: Institutions \\
\hline Estonia & 70.9 & 70.2 \\
Slovenia & 70.2 & 63.4 \\
Lithuania & 68.4 & 63.3 \\
Czech Republic & 70.9 & 60.9 \\
Latvia & 67.0 & 59.3 \\
Poland & 68.9 & 56.4 \\
Slovak Republic & 66.8 & 56.3 \\
Hungary & 65.1 & 55.7 \\
\hline
\end{tabular}

Source: Own preparation based on Schwab (2019).

Table 2.

Structure and composition of Pillar 1: Institutions in 2019 in CEE Countries

\begin{tabular}{|c|c|c|}
\hline Component & Worst performer & Best performer \\
\hline 1. Pillar: Institutions & Hungary & Estonia \\
\hline Security & Slovak Republic & Estonia \\
\hline 1.01 Organized crime & Slovak Republic & Estonia \\
\hline 1.02 Homicide rate & Latvia & Poland \\
\hline 1.03 Terrorism incidence & Poland & Multiple (7) \\
\hline 1.04 Reliability of police services & Slovak Republic & Estonia \\
\hline Social capital & Latvia & Slovenia \\
\hline 1.05 Social capital & Latvia & Slovenia \\
\hline Checks and balance & Hungary & Estonia \\
\hline 1.06 Budget transparency & Hungary & Estonia \\
\hline 1.07 Judicial independence & Poland & Estonia \\
\hline 1.08 Efficiency of legal framework in challenging regulations & Hungary & Estonia \\
\hline 1.09 Freedom of the press & Hungary & Estonia \\
\hline Public-sector performance & Slovak Republic & Estonia \\
\hline 1.10 Burden of government regulation & Slovak Republic & Estonia \\
\hline 1.11 Efficiency of legal framework in settling disputes & Slovak Republic & Estonia \\
\hline 1.12 E-Participation Index & Czech Republic & Estonia \\
\hline Transparency & Hungary & Estonia \\
\hline 1.13 Incidence of corruption & Hungary & Estonia \\
\hline Property rights & Poland & Estonia \\
\hline 1.14 Property rights & Hungary & Estonia \\
\hline 1.15 Intellectual property protection & Hungary & Estonia \\
\hline 1.16 Quality of land administration & Poland & Lithuania \\
\hline Corporate governance & Hungary & Slovenia \\
\hline 1.17 Strength of auditing and reporting standards & Poland & Slovak Republic \\
\hline 1.18 Conflict of interest regulation & Hungary & Slovenia \\
\hline 1.19 Shareholder governance & Estonia & Lithuania \\
\hline
\end{tabular}




\begin{tabular}{lcc}
\hline \multicolumn{1}{c}{ Component } & Worst performer & Best performer \\
\hline Future orientation of government & Poland & Estonia \\
1.20 Government ensuring policy stability & Poland & Estonia \\
1.21 Government's responsiveness to change & Slovak Republic & Estonia \\
1.22 Legal framework's adaptability to digital business models & Latvia & Estonia \\
1.23 Government long-term vision & Slovak Republic & Hungary \\
1.24 Energy efficiency regulation & Poland & Slovak Republic \\
1.25 Renewable energy regulation & Poland & Slovak Republic \\
1.26 Environment-related treaties in force & Multiple (2) & Multiple (3) \\
\hline
\end{tabular}

Source: Own preparation based on Schwab (2019).

\section{Chart 1.}

The change of GCI index: Pillar 1: Institutions in CEE Countries in the years 2007-2019 (standardized index $(1-100))$

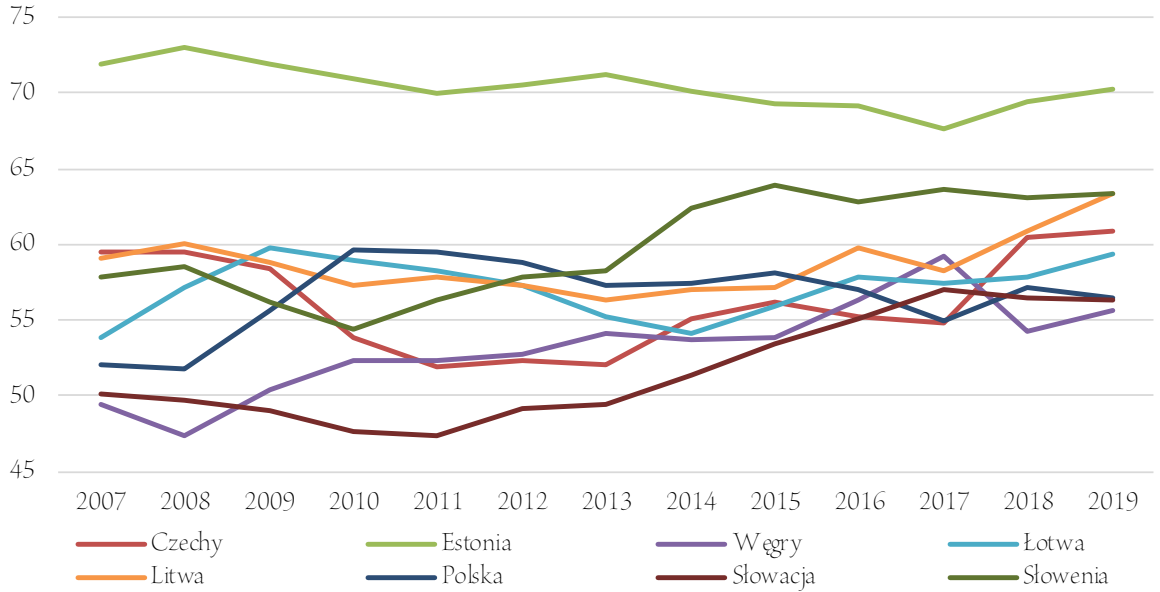

Source: Own preparation based on Schwab (2018, 2019) and World Bank (2020). 
Chart 2.

Mean of GCI index: Pillar 1: Institutions (horizontal axis) and the mean of FDI inflow per capita (vertical axis) in CEE countries in 2007-2019



Source: Own preparation based on UNCTADstat (2020) and World Bank (2020).

\section{Chart 3.}

Mean of GCI index: Pillar 1: Institutions (horizontal axis) and the mean of inflow of FDI as percentage of GDP (vertical axis) in CEE countries in 2007-2019

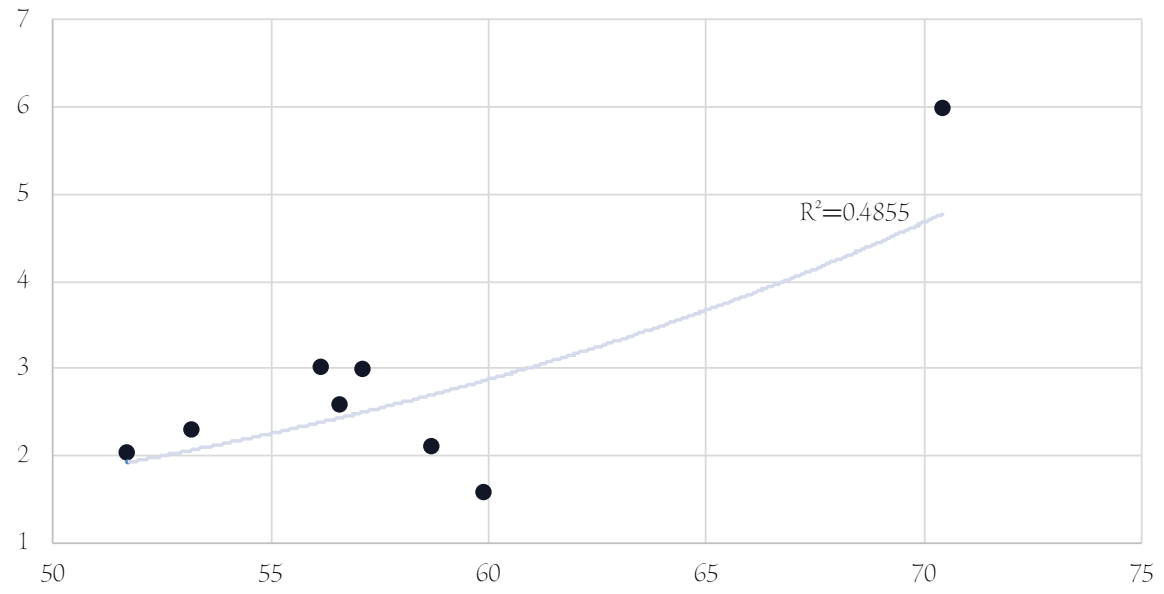

Source: Own preparation based on UNCTADstat (2020) and World Bank (2020). 